\title{
台風1330号ハイエンに対するフィリピン． レイテ島河川の洪水応答特性 FLOOD RUNOFF RESPONSES TO T1330 (HAIYAN) OF RIVERS IN LEYTE ISLAND, PHILIPPINES
}

\author{
呉修一1 - Maritess S. Quimpo ${ }^{2} \cdot$ Jeremy D. Bricker $^{3}$ - 真野明4 \\ Shuichi Kure, Maritess S. Quimpo, Jeremy D. Bricker and Akira Mano \\ 1正会員 博(工) 東北大学助教 災害科学国際研究所（９980-0845 宮城県仙台市青葉区荒巻字青葉468-1） \\ ${ }^{2}$ Dr. of Eng., Bureau of Research \& Standards, Department of Public Works and Highway \\ (EDSA, Diliman, Quezon City 1101, Philippines) \\ ${ }^{3}$ Member of JSCE, Ph.D., Associate Professor, International Research Institute of Disaster Science, Tohoku University \\ (Aoba 468-1 Aoba Sendai-shi Miyagi, 980-0845, Japan) \\ 4フェロー会員 工博 東北大学教授 災害科学国際研究所 \\ （干980-0845 宮城県仙台市青葉区荒巻字青葉468-1）
}

\begin{abstract}
Typhoon No.1330 (Haiyan) that struck the Philippines on November 8, 2013 caused over 7,000 casualties by remarkably high wind speed, storm surges and waves. In this paper, hydrologic responses to T1330 of the rivers in Leyte Island, Philippines were investigated based on the GSMaP satellite driven rainfall data, observed water depth in the rivers and an application of a rainfall runoff model to a river basin. From the analysis, several different responses to T1330 of the rivers were observed because of the differences of the rainfall patterns, spatial scales and characteristics of the basins. Furthermore, we confirmed that the applied rainfall runoff model relatively well reproduced the observed flood condition in the Lingayon River under limited data conditions. Also, a basic numerical test was conducted in order to evaluate storm surge-flood coupling effects on water levels in the downstream of the Lingayon River.
\end{abstract}

Key Words : Typhoon Haiyan, Philippines, hydrologic responses, predictions in ungauged basins

\section{1. はじめに}

台風1330号（ハイエン）は2013年11月8日にフィリピ ンに上陸し大きな被害を与えた。特にフィリピン・レイ テ島およびサマール島の人的被害が大きく, 本台風の フィリピン上陸時の勢力1) ${ }^{1}$ は, 中心気圧 $895 \mathrm{hPa}$, 最大風 速 $65 \mathrm{~m} / \mathrm{s}$, 瞬間最大風速 $90 \mathrm{~m} / \mathrm{s}$ と史上最大規模のスケール であり，高潮，高波や強風を伴い7,000人を超える死 者・行方不明者，100万棟を超える建物被害がフィリピ ンで生じた2). 人的被害は特にレイテ島北東沿岸部に位 置するタクロバン市，パロ町，タナウアン町に集中して おり，サンペドロ湾に発生した高潮の規模の大きさや沿 岸部の脆弱性を示唆するものである（例えば，呉ら3）．

本災害の発災後, 例えば, 土木学会・フィリピン土木 学会合同台風 30 号高潮災害調査グループ4) や著者らのグ
ループ5) が被害状況の把握を目的とした現地調査を実施 するとともに，本台風に伴い発生した高潮の数值計算が 多数実施されている(例えば, Moriら ${ }^{6)}$, Brickerら ${ }^{7)}$ ).

このように，本台風に伴う被害状況を明らかにするた めの取り組みや，高潮・高波の発生メカニズムを解明す るための解析が精力的に行われている. ここで一つの疑 問は，本台風横断時の降雨状況や河川水位の応答，士砂 災害や洪水の発生状況等はどのようであったかという点 である.このような水文学的観点からの本台風に対する 報告は，著者らの知る限りで存在しない，特に，台風時 の高潮と洪水の同時生起や土砂災害等の複合災害は，今 後の地球温暖化の影響を考慮した場合，しっかりとリス ク評価を行う事が重要となる（例えば，三澤ら ${ }^{8)}$ ）。

台風による降雨と高潮の同時生起に関して，端野・神 田 ${ }^{9}$ は，大阪湾に襲来した台風と降雨の関係を整理する ことで，最大潮位偏差が大きいほど洪水と高潮の同時生 
起確率が高くなる傾向を明らかにし, 洪水と高潮が同時 生起する確率が決して小さくない事を示している．また， 河川遡上を考慮した高潮の数值計算が村上・森川100 によ り実施されるとともに，原ら ${ }^{11}$ は，河川汇濫を考慮した 高潮推算手法を提案し, 波浪によるWave setupを考慮し た高潮推算と一般座標系による二次元不定流計算の結合 モデルを提案している，最近では，佐山ら ${ }^{12}$ は，2008年 5月にミャンマーを襲来したサイクロンナルギスを対象 とし，降雨流出氾濫モデルを用いることで高潮の汇濫シ ミュレーションを実施している.

このように, 潮位偏差が大きくなるような台風時は, 洪水と高潮を評価する事が重要となり, 台風1330号で甚 大な高潮が発生したレイテ島でも，河川の降雨に対する 応答特性や高潮と洪水のピーク時間差, 同時生起してい た場合の状況を評価する事は非常に重要である.よって 本論文は，本台風に対するフィリピン・レイテ島の雨 量・河川水位の状況を衛星雨量や現地データより明らか にするとともに, 利用可能なデータが少ない状況で洪水 の再現計算が可能か検討寸る. また，高潮と河川洪水が 同時生起した場合の基礎的な検討を行う事を目的とする。

\section{2. 台風1330号に伴うフィリピンの被害概要}

National Disaster Risk Reduction and Management Council の統計2)によると, 本台風に伴いフィリピンで, 死者 6,293 人，行方不明者 1,061 人，負傷者 28,626 人の人的被 害が生じ，全壊家屋550,928棟，半壊・一部損壊家屋は 589,404棟の建物被害が生じた（2014年4月3日時点）. 図-1にフィリピンのレイテ島・サマール島およびタクロ バン市，パロ町，タナウアン町の位置を示す.

図-2に，台風上陸時にタクロバン市で計測された，海 面更正気圧，平均風速，雨量の時系列を示寸，台風接近 に伴う圧力の急激な低下，風速・雨量の上昇が観測され ている. しかしながら，レイテ島上陸時の11月8日8:00 以降（フィリピン現地時間 [UTC+8 hrs]. 以後本論文の 時刻は全てフィリピン現地時間で記載. ) は，観測機器 が強風に伴い損壊し，データが久損している．このよう に，レイテ島やサマール島の水文・気象観測機材の多く は台風ピーク周辺時間のデータが取得できておらず，本 台風の風速等の大きさを如実に物語るとともに, 水文特 性を解明するのが難しい事を端的に示している，呉ら によると，このような強風に伴い，台風の経路に沿って 広域で建物被害が生じた。しかしながら，人的被害は， レイテ島北東部沿岸のタクロバン市，パロ町，タナウア ン町に $60 \%$ 以上が集中しており，サン・ペドロ湾で11月 8日6:30から8:00の間に発生した高潮が人的被害に大きく 寄与したことが報告されている. 本高潮の浸水高は，夕 クロバン市で6〜7 mにおよぶ事が報告され4),5), 沿岸部 の村では高潮による浸水で村民の $15 \%$ 以上が死亡した村

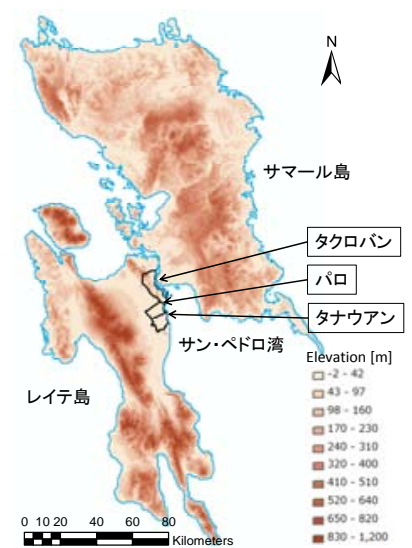

図-1 レイテ島, サマール島, タクロバン市, パロ町, タナウアン町の位置

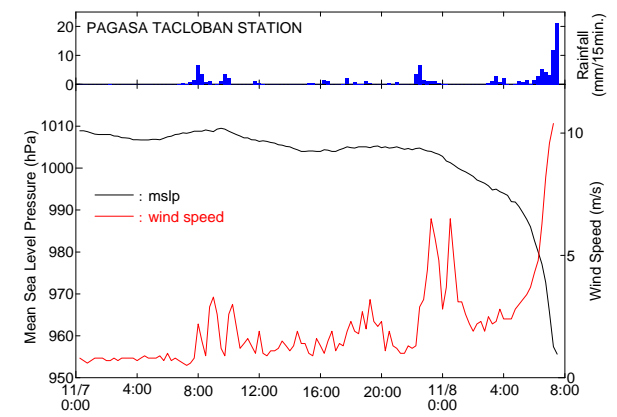

図-2 タクロバンにおける海面更正気圧, 平均風速, 雨量の時系列

が多く存在していた事が明らかになっている3).

\section{3. レイテ島雨量と河川水位の応答状況}

図-3に，台風時のフィリピンの3時間雨量の時空間分 布を示す．また，レイテ島・サマール島における72時間 雨量(11月6日21:00-9日20:00)の空間分布を図-4に示す. 雨量データは, GSMaP (JAXA)の衛星雨量13)を使用して いる. 図-3で台風の中心位置を青丸で示しているが，中 心時刻は3時間雨量の最後の1時間での位置である. 台風 の中心位置は, Unisys Weather ${ }^{14)} よ り$ 得ている. また, 図-4にはHydroSHEDSデータ(USGS ${ }^{15)}$ )より入手した河川 網を同時に図示している．図-3，4より，レイテ島で多 くの雨量が見られ， $250 \mathrm{~mm}$ 以上の3日間雨量がレイテ島 南部および北西部のグリッドで確認される.

著者らのグループが実施した現地調査5)では，本豪雨 に伴う顕著な斜面崩壊等の土砂災害は, 確認する事が出 来なかった，しかしながら，図-5に示寸パロ町を流れる Lingayon川では, 中流河川沿い居住者7名への聞き込み 調査より, 河川の洪水に伴い河川沿いの住居が床上浸水 する等，洪水も生じていた事を確認している.

図-5に, レイテ島の河川網および水深データを入手す る事ができた7河川名と観測位置を示寸．図-6に入手し た河川水位データの時系列を示寸とともに，表-1に各河 川の流域面積および総流路長を示す．図-6中に各観測地 
点の河口からの距離を, HydorSHEDSより求め示してい る（例えば，Lingayon川観測点の河口からの距離は18.5 $\mathrm{km}$ で，図中，Lingayon (18.5 KP) と明記）。水位データ は， Department of Public Works and Highwayレイテ島オ フィスより提供頂いた水深データに観測地点の標高デー タを加え表示している. 水深データは，職員が河川水深 ゲージを目視により 7:00，12:00，17:00の時刻に毎日計測 している．標高データに関しては，Lingayon川観測地点 は，RTX-GPS観測より算定し，その他の地点の標高は， HydroSHEDSデータより算定しているため，数mオー ダーの誤差がある点に注意されたい.

図-6より，河川水位の応答は各河川で異なり，レイテ 島北部に位置し流域面積の大きい， Lingayon川，

Sapinton川, Leyte川はハイドログラフの洪水継続時間が 長い傾向にあり水位上昇幅も大きいことがわかる．また， サン・ペドロ湾で発生した高潮の生起時刻が11月8日の 6:30-8:00程度であるが，河口部で高潮が発生していた Lingayon川の洪水ピークはそれよりも9時間程度遅れて いる．興味深いのは，レイテ島北部に位置するSapiniton 川およびLeyte川の台風に対する応答が，他の河川と異 なる点である．この理由としては，図-7に示すよう，台 風の横断に伴い, 降雨の初期ピークが西部ほど小さく, 降雨が遅い時間まで継続している等，降雨パターンが異 なる点がまず考えられる，また，Sapiniton川上流では初 期の強降雨が他のグリッド地点より弱く，これにより洪 水の立ち上がりが遅くなった可能性もある. その他にも， 両河川の源流は標高の高い山間部に位置しているため, 上流の土壌・地質特性等が他の河川と異なり，降雨に対 する流出の応答が遅い可能性が考えられる. しかしなが ら，上記考察は，本河川網が空間的に解像度の粗い（15 秒）標高データより作成されている点，詳細な土畩デー タが存在しない点，衛星雨量の空間解像度が粗く $(0.1$ 度 $)$ 不確実性がある点等，あくまでも推測の域である.

このような各河川の応答の相違や特徵等を，降雨流出 モデルを用いた再現計算から表現できる可能性がある. また，高潮と洪水がもし同時に生起した場合，下流部で 浸水被害が増加していた可能性も排除できない. よって, 以下では，利用可能なデータから本台風に伴う河川洪水 の再現が可能かを検討し，洪水と高潮が同時生起してい た場合の基本的な検討を行う.

\section{4. 河川洪水の再現計算}

河川洪水の再現可能性を検討するとともに，高潮と洪 水が同時生起していた場合の基礎的な検討を実施するた め, 降雨流出モデルを用い本台風時のLingayon川（流域 面積 $211 \mathrm{~km}^{2}$ ）の洪水再現計算を実施する. Lingayon川の 下流はパロ町を流れる河川であり，高潮で大きな浸水被 害が生じた地域に河口部を有する.

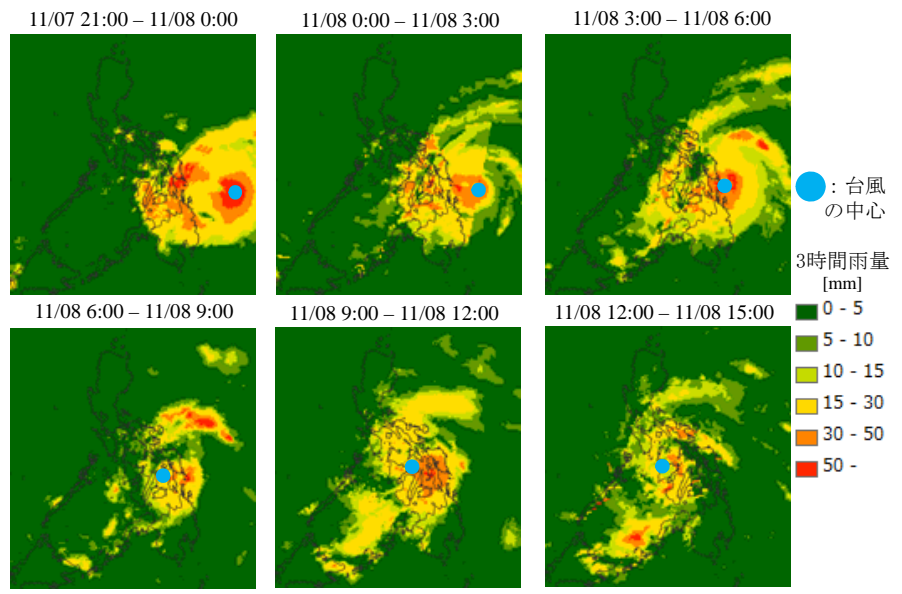

図-3ＧSMaPより得られた3時間雨量の時空間分布

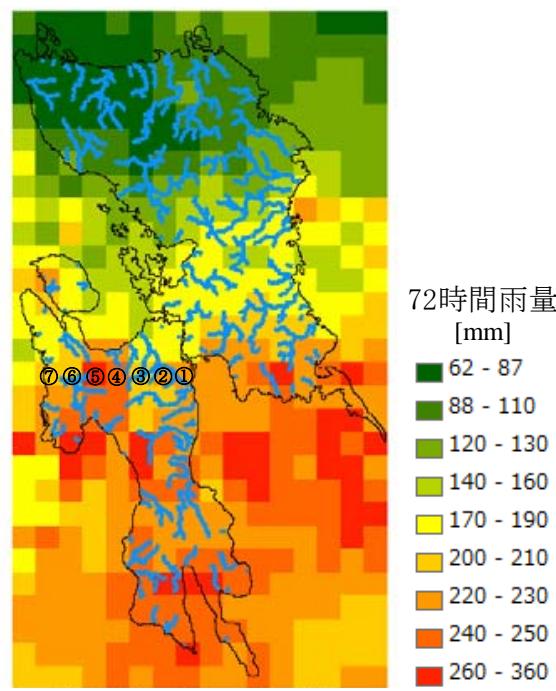

図-4ＧSMaPより得られたレイテ・サマール島の 72時間累積雨量（11月6日21:00-9日20:00)

降雨流出モデルは，吳ら而の土壤・地形特性に基づく 降雨流出計算手法を用いる．本手法は流域をサブ流域に 分割し, 各サブ流域で降雨流出計算を実行するサブ分布 型の流出計算手法である. サブ流域では，斜面流下方向 流れをkinematic wave法から集中化して計算を行う。モ デルパラメータは，表層土層厚や飽和透水係数などの土 壤・地形特性から決定される. 河道部における洪水波の 追跡には，以下に示す1次元不定流の式(1), (2)を用い計 算を行う。

$$
\begin{gathered}
\frac{\partial A}{\partial t}+\frac{\partial Q}{\partial x}=q_{l} \\
\frac{\partial Q}{\partial t}+\frac{\partial(u Q)}{\partial x}=g A \frac{\partial(h+z)}{\partial x}-\frac{g n^{2}|Q| Q}{R^{4 / 3} A}
\end{gathered}
$$

ここに, $A$ : 通水断面積, $Q$ : 河川流量, $q_{l}$ : 側方流入量, $u$ : 河川流速, $g$ : 重力加速度, $h:$ 水深, $z:$ 標高, $n:$ マニングの粗度係数, $R$ : 径深である. 本手法の詳細は 呉ら16)に詳しいのでそちらを参照されたい.

本手法の適用にあたり，標高データはHydroSHEDS データより入手し，その標高データを用い河道網や9つ のサブ流域の抽出を実施した. Lingayon川の土壌・地質 パラメータは, FAO Soilデータより表層土層厚（A層, 流域平均 : $24 \mathrm{~cm}$ ), 有効空隙率（流域一様 : 0.45）, 


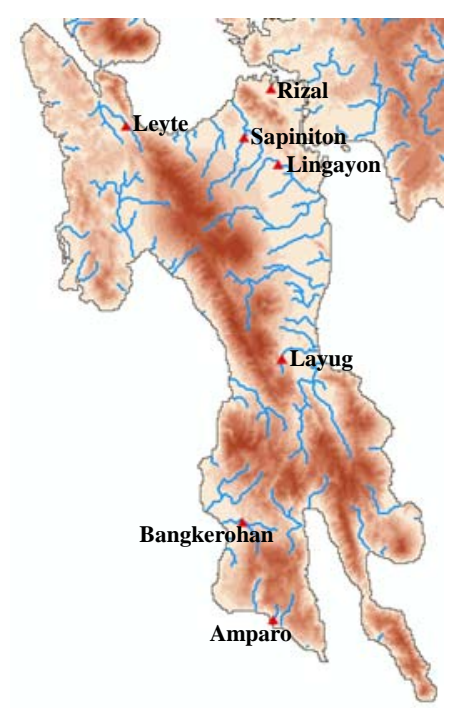

図-5 レイテ島河川網と水深データの存在する河川名

\section{表-1＼cjkstart各河川の流域面積と総流路長}

\begin{tabular}{|l||c|c|}
\hline River Name & Area $\left[\mathrm{km}^{2}\right]$ & Length $[\mathrm{km}]$ \\
\hline \hline Lingayon & 212.1 & 40.6 \\
\hline Sapiniton & 313.5 & 58.2 \\
\hline Rizal & 38.3 & 1.3 \\
\hline Leyte & 234.7 & 39.9 \\
\hline Layug & 130.1 & 17.5 \\
\hline Bangkerohan & 197.9 & 29.2 \\
\hline Amparo & 28.5 & 5.4 \\
\hline
\end{tabular}

飽和透水係数（流域平均 : $16.3 \mathrm{~mm} / \mathrm{h}$ ) を決定した ${ }^{17)}$. こ こで，表層土層のA 層厚は，FAO Soilより算定されるA 層厚の $10 \%$ と仮定して決定している，有効空隙率は流域 一様の值しか得ることが出来ないなど，FAO Soilデータ の空間分解能は非常に粗い点に注意されたい.

河道横断面データは，水深観測所地点とその上下流周 辺は現地調査で計測し, その他の横断面データは矩形断 面を仮定し，佐山ら ${ }^{18)}$ と同様に，Carpenterら ${ }^{19)}$ の手法よ り決定した。 下流から河口部の河道幅はGoogle Earthよ り計測し設定した.

河道部の 1 次元不定流計算の下流端境界条件は,

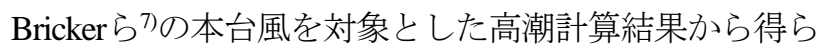
れた潮位の時系列データを使用し，入力雨量データは GSMaP雨量データを使用している。ここでGSMaP雨量 データは，前述のように不確実性を有するため， タクロ バン市でイベントの前半部のみ計測された実測雨量の総 量との比を用い，全体の総量を補正している．河道のマ ニングの粗度係数は実測の水深ピーク時刻に計算結果が 合うよう試行錯誤的に設定した.

Lingayon川中流部の水深観測所における，計算結果と 実測の比較を図-8に示す。初期のGSMaPで計測された 強い降雨の不確実性に伴い洪水の立ち上がりが実測と比 較して早いことがわかる。また，洪水の逢减部は，実測 より計算值が遅く逢减している。しかしながら, 利用可 能なデータを考慮した場合，全体的な洪水の挙動を再現 出来ていると言えるであろう.

このようにして再現された洪水を用いて以下では，洪
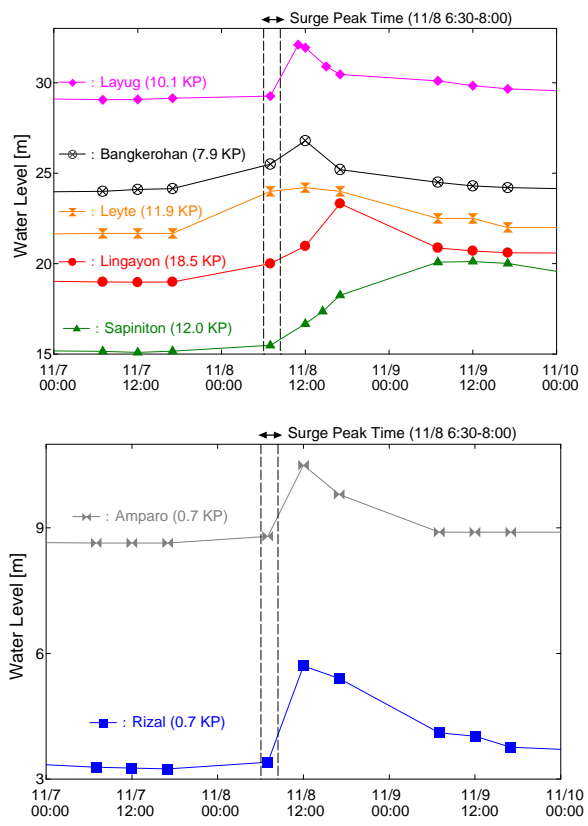

図-6 レイテ島河川の水位時系列

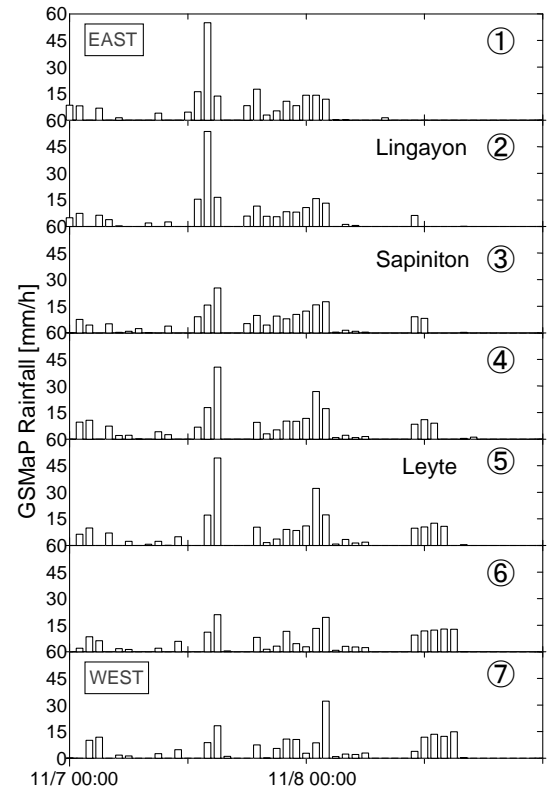

図-7 GSMaP雨量各グリッドの時系列. (1)から(8)に 向けて，東から西方向. 各グリッドの位置は 図-4に記載. (2)，(3)，(5)は，各記載河川の上流

水と高潮の同時生起が発生した場合を想定した，基礎的 な数值実験を行う.

\section{5. 洪水と高潮の同時生起に関する基礎的検討}

前述のように, Lingayon川の洪水ピーク時刻は河口部 での高潮生起時刻より9時間程度遅れていた。洪水と高 潮のピークが同時生起していた場合，下流部の水位が更 に上昇していた可能性が容易に考えられる．よって，基 本的な数值実験を行い，同時生起していた場合の水位の 上昇程度に関して検討する.

洪水ハイドログラフは上記で降雨流出モデルより再現 


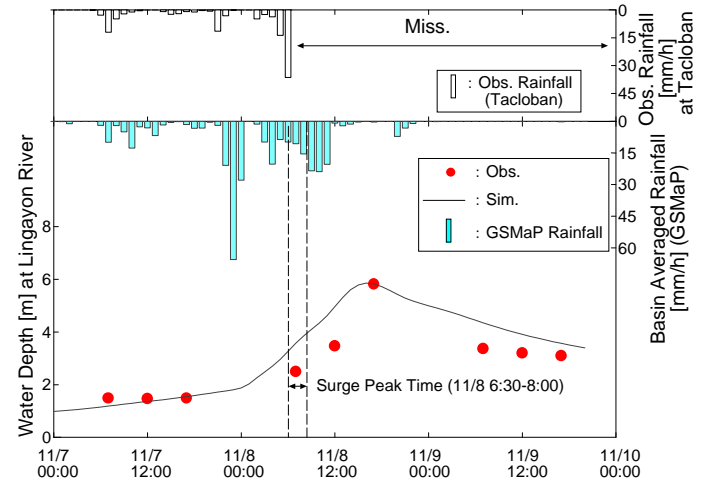

図-8Ｌingayon川における観測と計算值の比較

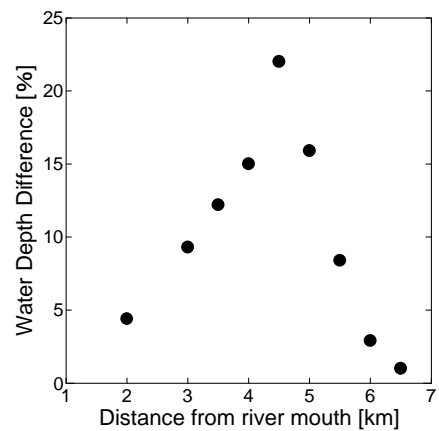

図-10 河口からの距離と最大ピーク水深差率の関係

した計算結果を用い，河道部における1次元不定流の式 の下流端境界条件で与えた高潮を含む潮位の時系列を， 時間方向にシフトし計算する事で，同時生起した場合の 下流部の水位を検証する。下流端境界条件で与えた潮位 を図-9に示す．この潮位の時系列を，高潮のピークが遅 れて発生するよう，1時間から9時間まで1時間間隔で時 間方向に後退させ，新たに9ケースの潮位データを仮想 的に作成した. これら仮想的な潮位の時系列を下流端境 界条件として計算を実施した。

計算結果として, 河口から $4.5 \mathrm{~km}$ 地点におけるハイド ログラフを図-9に同時に示す．高潮の生起時間が洪水 ピークに近づくほどピーク水位が高くなっている事がわ かり, 同時生起した場合はもとの水位よりも0.6 m (17\%) 上昇していることがわかる. 次に, 河口からの距離と, 最大ピーク水深差率を図-10に示寸. 最大ピーク水深差 率とは，(1)実際の洪水と高潮の生起時間が異なる場合の ピーク水深と，(2)洪水と高潮が同時生起した場合の最大 ピーク水深の差をとり，(1)で除し百分率で表示したもの である. 河口から6.5 km地点まで高潮が影響している事 がわかるとともに，河口から $4.5 \mathrm{~km}$ 地点で最も大きな水 深差が生じている.

しかしながら，上記数值計算は1次元不定流計算に基 づく基礎検討であり，原ら ${ }^{20}$ が既に指摘しているよう， 高潮の河道一の遡上計算を, 1次元計算の下流端境界条 件として，河口部で強制的に水位を制御する方法を用い 計算した場合，計算水位，流速に誤差が含まれる可能性 がある. これは, 河道と河口部の地形の複雑な接続を1 次元計算ではスムーズに表現できないためである.今後,

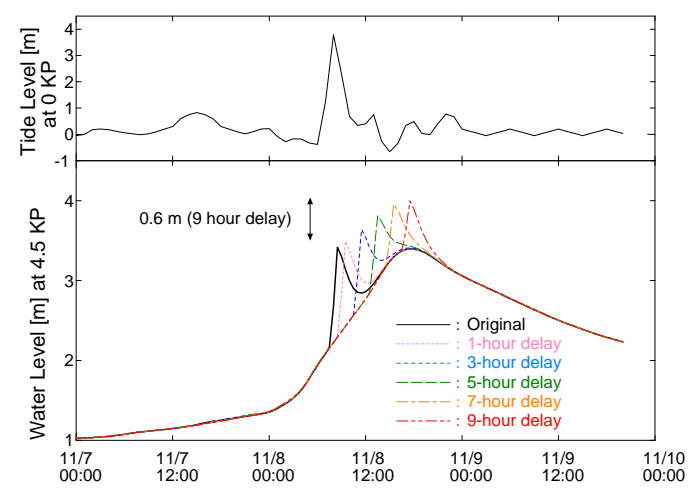

図-9＼cjkstart洪水と高潮の同時生起が河川水位に与える影響

この点を考慮するため河道部は1次元の計算，河口部は 水平 2 次元で解析する統合計算を実施する予定である. そのため, 今後詳細な河口部の地形測量を現地で実施し， 上記計算結果と1次元・2次元統合計算結果の比較を行う 予定である.

本論文の検討結果では，例え洪水と高潮が同時生起し ていても, 最大で水深が約20\%程度の上昇となった。 こ れは，対象とした高潮の面的な浸水高や被害を考慮した 場合, 複合災害として複雑に考慮する必要性が小さいと 考える事も出来る. 洪水と高潮の複合災害としての影響 が大きい状況は, 進行速度の遅い台風が長時間河口部の 水位を上昇させ，そこに通常の洪水が重複し洪水が増大 化するような場合等が想定される.よって，今後は各洪 水や高潮の特徵に応じて, 同時生起した場合の影響評価 を行い整理する事が重要となる.

\section{6. まとめ}

本論文は，フィリピンに甚大な被害をおよぼした台風 1330号 (ハイエン) の雨量状況やレイテ島河川水位の応 答特性を記述するとともに, 高潮被害の大きかったパロ 町を流れるLingayon川で洪水の再現計算を行ったもので ある.また，洪水と高潮のピークが同時生起した場合の 基礎的な数值実験を行い, 下流での水位検証を行った. 以下に得られた知見を列挙する.

1) 台風1330号の横断に伴い, フィリピンのレイテ島 では3日間で250 mmを超える雨量が, GSMaP衛星 雨量で観測されていた.

2) 台風の降雨イベントに伴い，レイテ島各河川で水 位の上昇が顕著に生じていた，各河川の応答特性 は, 流域面積, 流路長, 降雨パターン, 土壤特性 等に応じて異なっている.

3) サン・ペドロ湾での高潮の生起時刻は2013年11月8 日6:30から8:00程度だが，パロ町を流れるLingayon 川の洪水ピークは中流で11月8日17:00程度であり， 本台風で生じた高潮と洪水のピークには，9時間程 度の時間差が存在した。

4） Lingayon川を対象とした降雨流出計算を実施した結 
果, GSMaP雨量等の不確実性の高いデータを用い ても，ある程度は洪水の再現が可能である事を示 した.

5） Lingayon川下流部で数值実験を行った結果，洪水と 高潮が同時に生起していた場合，水深が下流部で 20\%程度上昇する可能性がある事を明らかにした。

今後は, 他の河川の洪水再現計算を実施し, 洪水応答 特性が異なる理由を定量的に評価するとともに，河口部 での1次元，2次元統合計算を実施する事でより詳細な高 潮の遡上特性を明らかにしていく予定である.

謝辞 : 本研究は, 東北大学災害科学国際研究所平成26年 度特定プロジェクト（代表 : 只修一）の支援を受けて実 施された. 本論文で使用した雨量・河川水位データは, DPWHレイテ島オフィスより提供頂いたものである.ま た, GSMaP衛星雨量（JAXA）データを本論文では使用 している. レイテ島での現地調査の実施にあたっては, フィリピン気象天文庁，独立行政法人国際協力機構 (JICA), パシフィックコンサルタンツ株式会社および フィリピン大学タクロバン校の学生に, 非常に多くのご 支援を頂いた．ここに記して謝意を表する.

\section{参考文献}

1)気象庁: 気象庁台風位置表 2013 年台風第3 0 号, http://www.data.jma.go.jp/fcd/yoho/data/typhoon/T1330.pdf 参 照 2014-9-30, 2013.

2) NDRRMC (2014): SitRep No.107 Effects of Typhoon "YOLANDA" (HAIYAN),

http://reliefweb.int/sites/reliefweb.int/files/resources/Update\%20Yol anda\%20Sitrep\%20107.pdf 参照 2014-9-30.

3) 点修一, Anawat Suppasri, Carine J. Yi, Erick Mas, Jeremy D. Bricker, 越村俊一, 真野明 : 台風ハイエンに伴うレイテ島沿 岸部の人的被害状況, 土木学会論文集B2 (海岸工学), Vol.70, No.2, pp.I_1446-I_1450, 2014.

4) Tajima, Y., T. Yasuda, B.M. Pacheco, E.C. Cruz, K. Kawasaki, H. Nobuoka, M. Miyamoto, Y. Asano, T. Arikawa, N.M. Ortigas, R. Aquino, W. Mata, J. Valdez, and F. Briones: Initial report of JSCEPICE joint survey on the storm surge disaster caused by Typhoon Haiyan, Coastal Engineering Journal, Vol. 56, No.1, pp.1450006-112, 2014.

5) Mas, E., Bricker, J. D., Kure, S., Adriano, B., Yi, C., Suppasri, A., and Koshimura, S.: Field survey report and satellite image interpretation of the 2013 Super Typhoon Haiyan in the Philippines, Nat. Hazards Earth Syst. Sci. Discuss., Vol.2, pp.3741-3767, 2014.

6) Mori, N., Kato, M., Kim, S., Mase, H., Shibutani, Y., Takemi, T., Tsuboki, K., and Yasud, T.: Local amplification of storm surge by Super Typhoon Haiyan in Leyte Gulf, Geophysical Research Letters, Vol.41, No.14, pp.5106-5113, 2014.

7) Bricker, J., H. Takagi, E. Mas, S. Kure, B. Adriano, C. Yi, and V.
Roeber: Spatial variation of damage due to storm surge and waves during Typhoon Haiyan in the Philippines, Journal of Japan Society of Civil Engineers, Ser. B2 (Coastal Engineering), Vol. 70, No. 2., pp. I_231-I_235, 2014.

8) 三澤公希, 風間聡, 鈴木武, 有働恵子, 手塚翔也 : 気候変動 下の洪水と高潮の複合災害リスク推定, 土木学会論文集G (環境), Vol.70, No.5, pp.I_95-I_100, 2014.

9) 端野道夫, 神田徹 : 台風による降雨と高潮の同時生起性につ いて，水理講演会論文集, Vol.27, pp.1-10, 1983.

10) 村上和男, 森川雅行 : 河川遡上を考慮した高潮の数值計算, 海岸講演会論文集, Vol.31, pp.213-217, 1984.

11) 原信彦, 山田正, 柴木秀之 : 一般座標系による河川氾濫を 考慮した台風7010号野高潮推算, 海洋開発論文集, Vol.26, pp.435-440, 2010.

12) 佐山敬洋, Lin, N. M., 深見和彦, 田中茂信, 竹内邦良 : 降 雨流出汇濫モデルによるサイクロンナルギス高潮氾濫シミュ レーション, 土木学会論文集B1 (水工学), Vol.67, No.4, pp.I_529-I_534, 2011.

13) Aonashi, K., Awaka, J., Hirose, M., Kozu, T., Kubota, T., Liu, G., Shige, S., Kida, S., Seto, S., Takahashi, N. and Takayabu, Y.N.: GSMaP passive, microwave precipitation retrieval algorithm: Algorithm description and validation, J. Meteor. Soc. Japan, 87A, 119-136, 2009.

14) Unisys Weather: Individual Storm Details, Super Tyophoon-5 Haiya, http://weather.unisys.com, 参照 2014-9-30, 2013.

15) US Geological Survey: Hydrological data and maps based on Shuttle Elevation Derivatives at multiple Scales, http://hydrosheds.cr.usgs.gov/index.php, 参照 2014-9-30, 2010.

16) 呉修一, 山田正, 吉川秀夫 : 表面流の発生機構を考慮した 斜面多層降雨流出計算手法に関寸る研究, 土木学会水工学論 文集, Vol.49, pp.169-174, 2005.

17) Kure S., Jang, S., Ohara N., Kavvas, M.L., Kavvas, and Chen, Z.Q.: Hydrologic Impact of Regional Climate Change for the Snowfed and Glacierfed River Basins in the Republic of Tajikistan: Hydrological Response of flow to Climate Change, Hydrological Processes, Vol.27, No.26, pp.4057-4070, 2013.

18) 佐山敬洋, 藤岡奨, 牛山朋來, 建部裕哉, 深見和彦: イン ダス川全流域を対象とした2010年パキスタン洪水の降雨流出 汇濫解析, 土木学会論文集B1 (水工学), Vol.68, No.4, pp.I_493I_498, 2012.

19) Carpenter, T.M., Sperfslage, J.A., Georgakakos, K.P., Sweeney, T., and Fread, D.L.: National threshold runoff estimation utilizing GIS in support of operational flash flood warning systems, Journal of Hydrology, Vol. 224, pp.21-44, 1999.

20) 原信彦, 山田正, 柴木秀之 : 一般座標系による河川分流を 考慮した高潮・洪水同時生起の数值シミュレーション, 土木 学会論文集B2 (海岸工学), Vol.B2-65, No.1, pp.246-250, 2009.

(2014. 9. 30受付) 